\title{
最近の廃棄物処理技術の動向
}

\section{The Latest Tendency of Waste Treatment Technology}

\section{石原 秀郎}

Hideo ISHIHARA

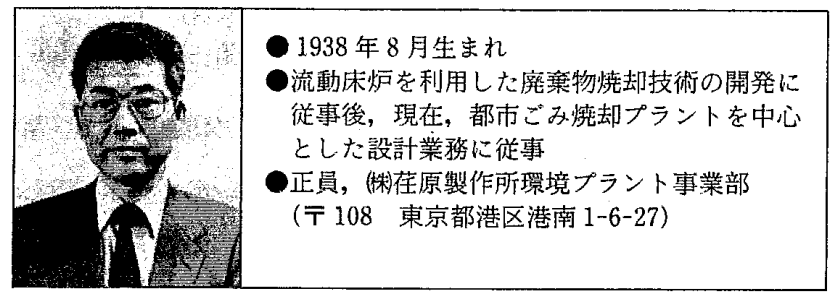

\section{1.はじめに}

昭和 40 年代の中ばに始まった高度成長期を背 景にして廃稁物処理技術も大きく転換した。その 大きな要因にごみ質とごみ量がある。すなわち, プラスチック素材に代表される高分子素材製品が 世に出回り，その結果がごみの発熱量の上昇につ ながり焼却処理においてもその方式に大きな変化 があった，現在，ごみ処理のうち焼却比率は全国 平均で約 70\%である. 欧米のごみ質に近づく昨 今の高カロリごみ発熱量は, プラスチック, 紙と いった組成の割合がいちだんと増加しているため であり，高度経済成長亡共にごみ量，ごみ質とも 第三の変換期をむかえていると言える.

高カロリごみの焼却技術に焦点をしぼって廃棄 物処理技術の一部を整理してみる。

\section{2. 最近の高カロリごみに対する焼却技術}

$2 \cdot 1$ 高温燃焼への移行高力ロリごみを焼 却した場合, 燃焼温度の上昇を防ぐために, 水や 空気で冷却する結果, ガス量の増加をまねき，炉 本体及びガス処理設備が大形化, 複雑化してい る.またプラスチック等の中には焼却処理工程に おいて所定の温度では分解出来ないダイオキシン

Jour. JSME
などの有害分質の発生が懸念される。こういった 問題を解決するために高温で安定した燃焼技術の 開発が遠からず必要である。

（1）高温燃焼実験 日本機械学会では，炉出 口の燃焼ガス温度を目標として $1000 \sim 1100^{\circ} \mathrm{C}$ 位 まで上げた時の炉に与える影響や燃焼ガス組成 （有害物質濃度）などについて調査した。現在， 稼動中のストーカ式, 流動床式焼却施設を利用し て行った実験例の一部を下記に示す。

(a) ストーカ式図 1 に施設のフローシート を示す(1)(2). 施設規模は $70 \mathrm{t} / 24 \mathrm{~h} \times 2$ 基で中規模 クラスである。実験は一般ごみ, 並に一般ごみに プラスチックを混入させたごみが使用された。そ れぞれのごみの低位発熱量は $H_{u}=1800 \sim 2000$ $\mathrm{kcal} / \mathrm{kg}, H_{u}=1900 \sim 3000 \mathrm{kcal} / \mathrm{kg}$ の発熱量で あった。表 $1^{(2)}$ は運転状況の測定結果を示してい る.

運転結果から言えることは，過剩空気をおさえ ることにより, 高温化がなされ, 熱回収効率（蒸 気発生量/ごみ処理量）が上昇している。一方, 排ガス中の $\mathrm{CO}, \mathrm{HC}$ が通常より高くなり，その 結果として $\mathrm{NO}_{x}$ が下がってきた。

(b) 流動床式 図 2 に施設のフローシートを 示す(1)(2). 施設規模は $130 \mathrm{t} / 24 \mathrm{~h} \times 3$ 基である. 運 転結果を表 2 に示す。表における RUN No. 3 で 発熱童が低く測定されたがサンプリン時のごみの 影響と思わ机る。その結果として能力が下がって いるにもかかわらず苲気量が多くなっているの は，発熱量がアップしていることを示している。 炉内で発生する塩化水素は炉内に投入されるド ロマイトによって中和される. RUN No.3 で $\mathrm{HCl}$ 濃度が上がっているのは発生した $\mathrm{HCl}$ 濃度 
が設計值をはるかにオーバしたため，煙突からの 排出量も並行してオーバしたことが言える。高温 燃焼時排がス中にCOの増加がタられた。逆に $\mathrm{NO}_{x}$ は減少の傾向が示された。一方，熱灼減量 は飛灰，ボイラ灰，焼却灰共，通常運転時との差 はみられなかった。

（2）高温燃焼の意義プラスチック混合率の 高い高カロリごみにとって高温燃焼は効果的な方 法である。一方，通常の発熱量ごみにとってもプ
ラス要素が大きい。

高温燃焼の方法と利点について考えてみたい. 高温化の方法 ${ }^{(2)(3)}$
(a) 低空気比運転
(b) 予熱空気温度の上昇
(c) 燃焼効率のアップ (熱枃隇量を改善)
(d) 燃燒方式の改善（例，二段燃焼の徹底）
(e) 炉体構造の考慮

などが考えられる。

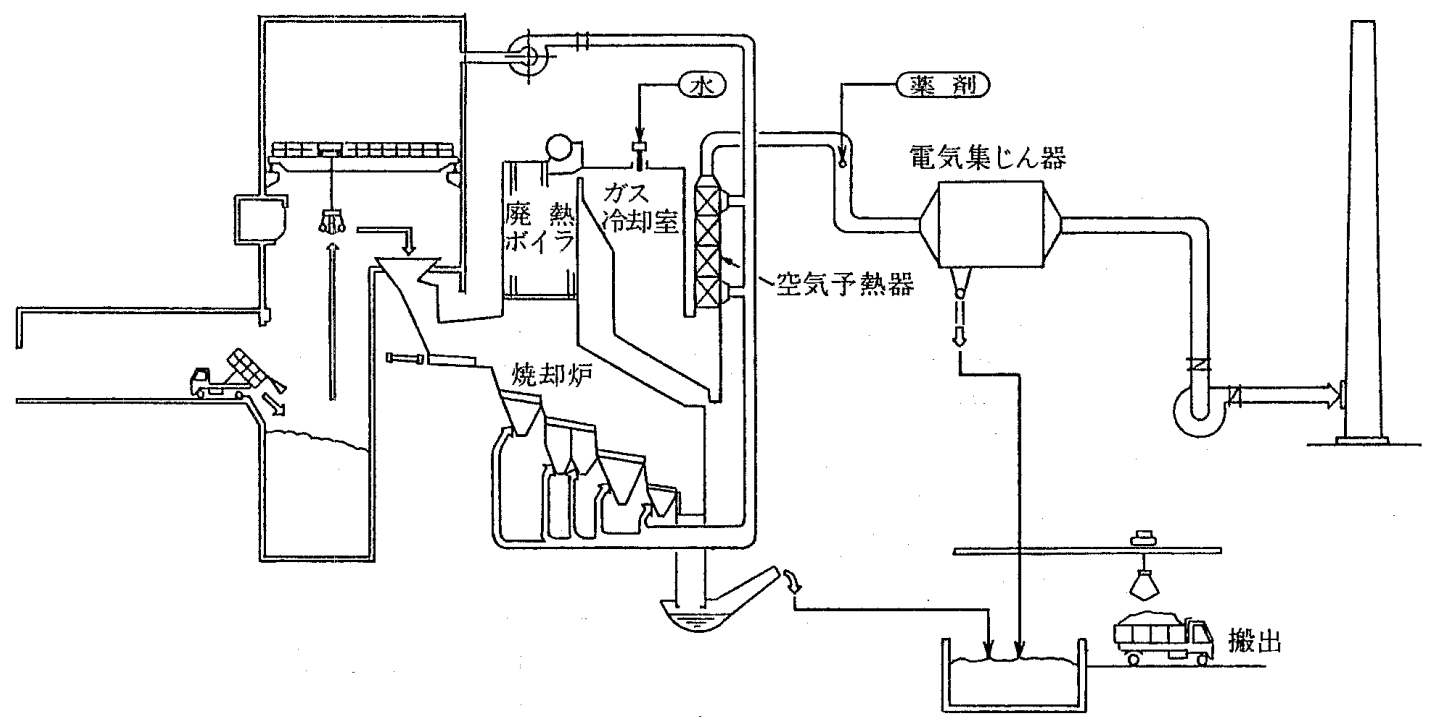

図 1 ストーカ式焼却施設フローシート

表 1 測定結果総括表

\begin{tabular}{|c|c|c|c|c|c|c|c|c|}
\hline \multirow[b]{2}{*}{ 項 } & \multirow[b]{2}{*}{ 単 位 } & \multicolumn{3}{|c|}{ 一般ごみ燃焼 } & \multicolumn{3}{|c|}{ 高プラスチックごみ混焼 } & \multirow[b]{2}{*}{ 備 } \\
\hline & & $\begin{array}{c}\text { ケース(1) } \\
900^{\circ} \mathrm{C}\end{array}$ & $\begin{array}{l}\text { ケース(2) } \\
1000^{\circ} \mathrm{C}\end{array}$ & $\begin{array}{c}\text { ケース(3) } \\
1100^{\circ} \mathrm{C}\end{array}$ & $\begin{array}{c}\text { ケース(4) } \\
900^{\circ} \mathrm{C}\end{array}$ & $\begin{array}{c}\text { ケース(5) } \\
1000^{\circ} \mathrm{C}\end{array}$ & $\begin{array}{c}\text { ケース(6) } \\
1100^{\circ} \mathrm{C}\end{array}$ & \\
\hline ご み 焼 却 量 & $\mathrm{t} / \mathrm{h}$ & 2.43 & 3.08 & 2.96 & 1.69 & 2.56 & 2.71 & \multirow{8}{*}{ 連続測定值 } \\
\hline 炉 内 水噴 霧 量 & $\mathrm{t} / \mathrm{h}$ & 0.10 & 0 & 0 & 0.26 & 0.21 & 0 & \\
\hline ガ ス 冷 水噴射量 & $\mathrm{t} / \mathrm{h}$ & 1.94 & 2.85 & 2.63 & 1.18 & 2.48 & 2.70 & \\
\hline 蒸 気 流 量 & $\mathrm{t} / \mathrm{h}$ & 2.77 & 3.53 & 3.46 & 2.39 & 3.56 & 4.01 & \\
\hline 排 ガ ス 流 量 & $\mathrm{Nm}^{3} / \mathrm{h}$ & 18240 & 22540 & 31300 & 16990 & 20280 & 21650 & \\
\hline ボイラ出口 & $\%$ & 7.8 & 7.2 & 5.7 & 8.8 & 5.6 & 5.3 & \\
\hline $\mathrm{NO}_{x}$ & ppm & 54 & 78 & 75 & 66 & 56 & 75 & \\
\hline $\mathrm{HCl}$ & ppm & 660 & 610 & 720 & 1310 & 1591 & 1470 & \\
\hline ばいじん & $\mathrm{g} / \mathrm{Nm}^{3}$ & 2.39 & 1.82 & 1.67 & 1.94 & 1.86 & 2.11 & \multirow[t]{2}{*}{ 手分析値 } \\
\hline $\mathrm{E} / \mathrm{P}$ 出口 & $\%$ & 7.9 & 7.4 & 7.5 & 10.9 & 8.5 & 7.9 & \\
\hline $\mathrm{NO}_{x}$ & ppm & 50 & 61 & 61 & 72 & 58 & 79 & \multirow{2}{*}{ 連続測定値 } \\
\hline $\mathrm{HCl}$ & ppm & 148 & 149 & 147 & 188 & 185 & 187 & \\
\hline $\mathrm{SO}_{2}$ & $\mathrm{ppm}$ & 34 & 39 & 42 & 46 & 47 & 49 & \multirow[b]{2}{*}{ 手分析値 } \\
\hline ばいじん & $\mathrm{g} / \mathrm{Nm}^{3}$ & 0.0011 & 0.0008 & 0.0012 & 0.0012 & 0.0011 & 0.0027 & \\
\hline
\end{tabular}

（注） 1 . 記載数值は, 測定值の実験時間中の平均値を示す.

2. $\mathrm{HCl}, \mathrm{NO}_{x}$ 值は $\mathrm{O}_{2} 12 \%$ 換算值を示す. 
高温燃焼の利点

（a）炬本体，通風装置，ガス処理装置のコンパ クト化

(b) 熱回収（蒸気回収）効率の上昇

(c) 運転経蒷の節減

(d) 微量有害物質の高温化による分解

しかしながら，長期的な運転が十分に行われた 例はまだない，長期運転をふまえたいくつかの検 討課題も残されている。例えば，

（a）クリンカの発生防止流動床炉から排出 される飛灰の中には流動媒体に使用される $\mathrm{SiO}_{2}$
の粉末が含まれる。これらは $1100^{\circ} \mathrm{C}$ を越えると 軟化し始め, 炉壁面への付着の心配が出てくる。 十分な温度管理が必要であるう。

(b) 酎火材の損傷防止高力ロリごみの局部 燃焼による高温化で耐火材の損傷，ならびにクリ ンカ現象の発生

（c）低空気此運転による不完全燃焼低空気 比運転は二次燃焼部での未燃ガスと空気との十分 な混合かくはんが前提である。不十分な混合かく はんは排がス中に CO の増加を招く恐れがある。 ダイオキシンとか，その前駆物質を分解させるこ

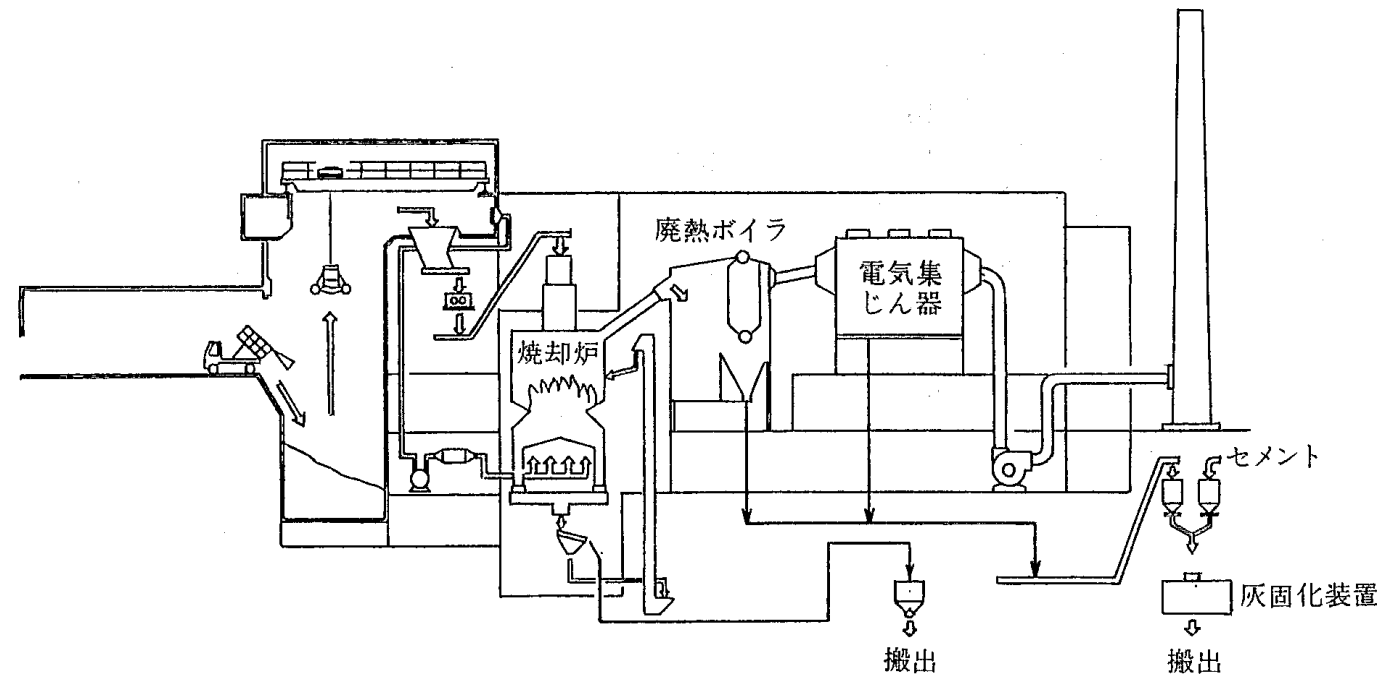

図 2 流動床式焼却施設フローシート

表 2 運転状況及び排ガスの測定結果

\begin{tabular}{|c|c|c|c|c|c|}
\hline & & RUN No. 1 & RUN No. 2 & RUN No. 3 & \\
\hline 項 & 単 位 & $\begin{array}{c}900^{\circ} \mathrm{C} \\
\text { 一般ごみ }\end{array}$ & $\begin{array}{c}950^{\circ} \mathrm{C} \\
\text { 高カロリごみ }\end{array}$ & $\begin{array}{c}1000^{\circ} \mathrm{C} \\
\text { 高力ロリごみ }\end{array}$ & 備 \\
\hline ごみ発熱量 & $\mathrm{kcal} / \mathrm{kg}$ & 2185 & 1752 & 1844 & 4 検体を混合し 1 検体として分析 \\
\hline ごみ暁却 量 & $\mathrm{t} / \mathrm{h}$ & 5.22 & 5.04 & 4.12 & テスト時間中の平均值 \\
\hline 蒸 気 流 量 & $\mathrm{t} / \mathrm{h}$ & 10.68 & 11.21 & 12.36 & テスト時間中の平均值 \\
\hline 排ガス 量（乾） & $\mathrm{Nm}^{3} / \mathrm{h}$ & 34555 & 33435 & 33880 & 2 回の平均値 \\
\hline 炉 頂 温 度 & ${ }^{\circ} \mathrm{C}$ & 901 & 950 & 999 & 2 回の平均値 \\
\hline ボイラ入ロ温度 & ${ }^{\circ} \mathrm{C}$ & 780 & 820 & 870 & 概略平均値（連続記録計） \\
\hline 空 気 温 度 & ${ }^{\circ} \mathrm{C}$ & 49 & 51 & 54 & テスト時間中の時間平均値 \\
\hline 炉内水噴霧 量 & $l / \mathrm{h}$ & - & - & - & \\
\hline 炉 出 口 $\mathrm{O}_{2}$ & $\%$ & 11 & 10 & 9 & 概略平均値（連続記録計） \\
\hline 炉出口 $\mathrm{NO}_{x}$ & ppm & 82 & 83 & 56 & 2 回の $\mathrm{O}_{2} 12 \%$ 平均値 ( 3 検体/回) \\
\hline 炉出 口 $\mathrm{HCl}$ & ppm & 82 & 89 & 236 & 2 回の $\mathrm{O}_{2} 12 \%$ 平均值 ( 3 検体/回) \\
\hline 炉出ロダスト & $\mathrm{g} / \mathrm{Nm}^{3}$ & 0.0012 & 0.0075 & 0.0155 & 2 回の $\mathrm{O}_{2} 12 \%$ 平均值 ( 1 検体/回) \\
\hline 熱灼減量 (灰) & $\%$ & 1.0 & 0.1 以下 & 1.5 & 3 検体を混合し 1 検体として分析 \\
\hline 熱灼減量 (不燃) & $\%$ & 0.1 以下 & 0.1 以下 & 0.1 以下 & 3 検体を混合し 1 検体として分析 \\
\hline ドロマイト投入量 & $\mathrm{kg} / \mathrm{h}$ & 500 & 500 & 500 & \\
\hline
\end{tabular}


とからも高温燃焼は有意義であると言われている が, 高温燃焼が唯一の有害物質の安定化の方法で はない事も記して扔く。

\section{3. 排ガス処理対策}

焼却排分スは，大気活染防止法によって煙突か ら排出される污染物質の濃度で規制されている。 さらに最近ではダイオキシンとか重金属のような 有害物質の挙動が問題化しつつあり，その対策に ついても燃焼技術や排分ス処理装置が注目されて いるが，確かな技術の確立は今後の重要な課題と 思われる。ここでは最近の大気污染複合処理技 術, 触媒脱硝技術について述べる。

$3 \cdot 1$ 大気污染複合処理技術 主として, ば いじんと有害ガスを同時に，または別々に処理す る技術をいう。多くのシステムが考えられるが， 代表的な例としては下記の分類が考えられる。す なわち,

\section{反応塔＋バグフィル夕}

電気集じん器十湿式ガス処理システム いずれも，ばいじん， $\mathrm{HCl}, \mathrm{SO}_{x}$ のみならず重金 属，その他の有害物質除去を目的とした高度排ガ ス処理システムである。

（1）反応塔十バグフィルタ(4) 消石灰粉末を 中和助浏として使用する反応塔により $\mathrm{HCl}, \mathrm{SO}_{x}$ を中和安定物質にして後段のバグフィルタで補集 する。

バグフィルタでは排ガス中のダストを補集する と同時に未反応な消石灰によりさらに酸性物質が

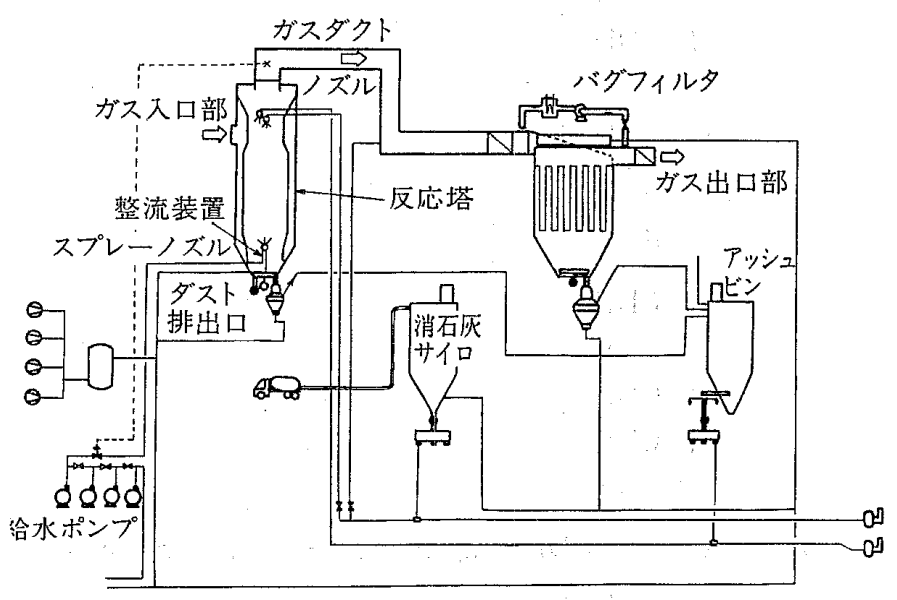

図 3 反応塔ならびにバグフィルタ
中和される。また重金属やダイオキシンも反応塔 からバグフィルタ間で，極微粒子ダス卜に吸着さ れ，同時にバグフィルタで補集される。図 3 に反 応塔とバグフィルタを組合わせた概念図を示す。

(2) 湿式ガス処理システム吸収塔方式が主 体であり，水酸化カルシウム水溶液，または，か 性ソーダ水溶液によって気液接触反応により有害 ガスが除去される。

性能的には $\mathrm{HCl}$ 除去率 $99 \%$ 以上も可能なもの もあるが, 反面, 白煙防止, 高度排水処理, 腐食 対策が必要であるため, 設備費が高くなり,これ らの補助設備を含めたユーティリティーコストも 乾式に比較して若干高価なものとなる。

最近では重金属などの有害物質除去を含めた高 度な湿式排がス処理設備が，ヨーロッパの都市ご み焼却設備にも普及しつつある。その一例である 「EDV システム」（フランス，LAB 社）を紹介す る.塩化水素, フッ素, 硫黄酸化物などの有害ガ スのほか, 水銀, カドミウム, 鉛, クロムなどの 重金属類, 炭化水素, ダイオキシン類などに対し て高い洗浄，集じん効果を有している．図 $4^{(5)(6)}$ にそのフローシートを示す。

電気集じん器で粗いばいじんを除去された排力゙ スは，急冷吸収塔においててスラリースプレーが可 能な特殊なノズルにより急冷され，同時に酸性ガ スが中和される。

ガス吸収，及び残りの粗い粒子を除じんされた 排ガスはベンチュリタイプの湿式電気集じん器 (図 5$)^{(5)(6)}$ に誘引され，サブミクロンの微細粒子 が除去される。 $0.1 \mu \mathrm{m}$ 以下の微粒子はベンチュ リ内でコロナ放電により容易にマイナスに带電さ せ，これをべンチュリの出ロでプラスに帯電され た水スプレー水膜に電気的に吸収させて除去す る。小形で圧損が少なく除じん効率, 有害物質の 吸収効率が高いのが特長である。

EDV システムを利用したオーストリア，ウィ ーン市の都市ごみ焼却場における排ガス処理設 備, 污染物質除去例を表 $3^{(7)}$ に示す。

$3 \cdot 2$ 窒素酸化物低減対策ももともとごみ焼 却炬には燃焼時に発生するアンモニア, 一酸化炭 素といった未燃ガスによって $\mathrm{NO}_{x}$ を還元する自 己脱硝反応が存在する。一般にごみ焼却炉で採用 されている $\mathrm{NO}_{x}$ 低減対策の方法を表 4 に示 
す(3). 実際には発生抑制技術が先行し，規制条件 の適用範囲によって除去技術が附加される。ここ では触媒脱硝技術についてふれておく。

還元剤としてアンモニアガスを用い触媒層の中 を $400^{\circ} \mathrm{C}$ 以下の温度で排がスとアンモニアを通 し，脱硝を行う乾式プロセスである，触媒として は低温活性と耐 $\mathrm{SO}_{x}$ 的に優れたバナジウム系を 用い，形状としては，八二カ厶状，板状，ペレッ 卜状触媒がある。日本機械学会がペレットならび にハニカム状の触媒を用いて行った実験の脱硝特 性を図 $6,7^{(1)}$ に示す。この方法は触媒のコスト がプラント全体のランニングコストを左右する。

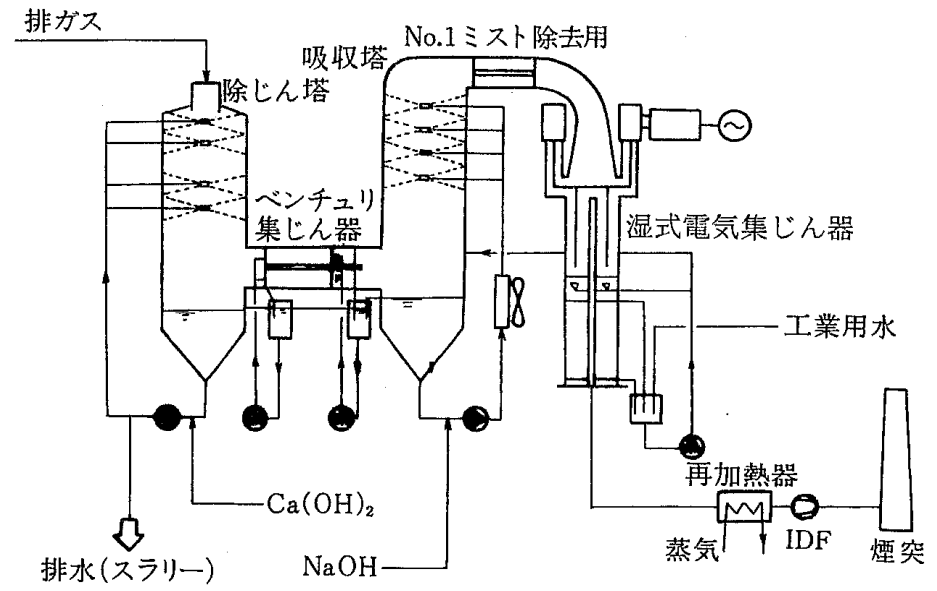

図 4 EDV プロセスフロー

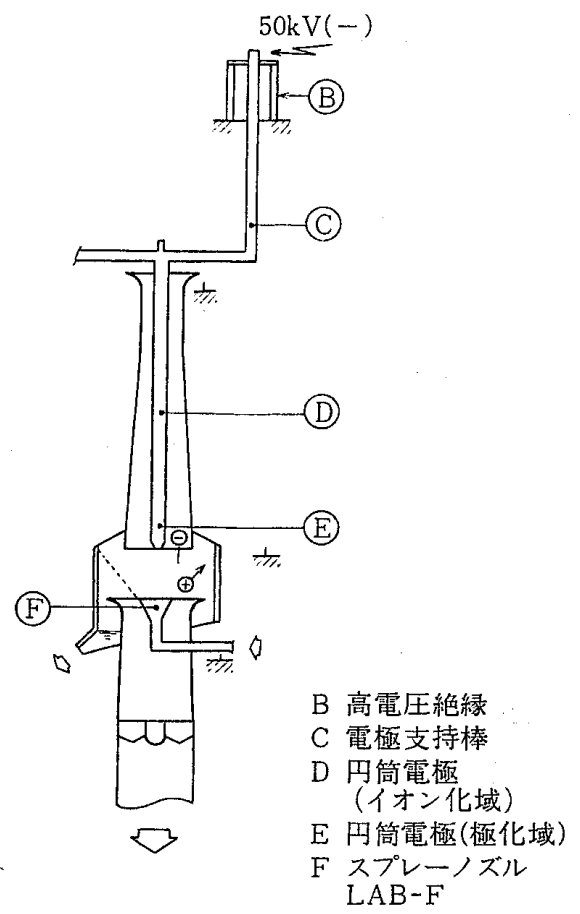

図 5 ベンチュリ式湿式電気集じん器
従って触媒の寿命が本法の可否に大きく影響をも たらす。しかしながら現状に扔いてはある運転条 件下で，性能的に安定した結果が得られるため， 一部の施設ですでに採用されている。

\section{4.あとがき}

4 ～5 年前までは高質ごみといわれた都市ごみ の発熱量は $2000 〜 2300 \mathrm{kcal} / \mathrm{kg}$ であり，サンプ

表 3 EDV (湿式電気集じんベンチュリ)による 微量污染物質除去例（ウィーン市フレッ シェルシュタイク実績例)（1986 年）

\begin{tabular}{|c|c|c|c|}
\hline 污染物筫 & $\begin{array}{l}\text { 入 口 } \\
\text { 測定值 }\end{array}$ & $\begin{array}{l}\text { 出口 } \\
\text { 測定值 }\end{array}$ & $\begin{array}{l}\text { オーストリア } \\
\text { 規 制 值 } \\
1986 \text { 年 } 5 \text { 月 }\end{array}$ \\
\hline 塩化水素 $\mathrm{HCl}$ & 750 & 3.7 & $30(27)$ \\
\hline フッ化水素 HF & 5 & 0.2 & $5(4.5)$ \\
\hline 硫黄酸化物 $\mathrm{SO}_{2}$ & 500 & 30 & $500(450)$ \\
\hline 全ダスト量 & 450 & 11 & $25(22)$ \\
\hline $\begin{array}{l}\text { 重金属 } \\
\text { 水銀 } \mathrm{Hg}\end{array}$ & 0.5 & 0.04 & $0.10(0.09)$ \\
\hline カドミウム Cd & 0.25 & 0.008 & $0.10(0.09)$ \\
\hline $\begin{array}{c}\text { 鉛 } \mathrm{Pb} \\
\text { 垔鉛 } \mathrm{Zn}\end{array}$ & 12.5 & $\begin{array}{c}1.2 \\
0.56\end{array}$ & $5.0(4.5)$ \\
\hline 七素 As & - & $<0.09$ & $1.0(0.9)$ \\
\hline クロム $\mathrm{Cr}$ & - & $<0.1$ & $4.0(3.6)$ \\
\hline $\begin{array}{c}\text { ダイオキシン } \\
\text { : PCDDs }\end{array}$ & 74.7 & 4.0 & - \\
\hline$T 4 \mathrm{CDD}$ & - & 0.9 & - \\
\hline P 5 CDD & - & 0.6 & - \\
\hline $\mathrm{H} 6 \mathrm{CDD}$ & - & 1.0 & - \\
\hline H7 CDD & - & 0.8 & - \\
\hline O $8 \mathrm{CDD}$ & - & 0.7 & - \\
\hline $\begin{array}{c}\text { ジベンゾフラン } \\
\text { : PCDFs }\end{array}$ & 56.2 & 27.6 & - \\
\hline T $4 \mathrm{CDF}$ & - & 14.4 & - \\
\hline $\mathrm{R} 5 \mathrm{CDF}$ & - & 7.6 & - \\
\hline $\mathrm{H} 6 \mathrm{CDF}$ & - & 3.6 & - \\
\hline $\mathrm{H} 7 \mathrm{CDF}$ & - & 1.7 & - \\
\hline $\mathrm{O} 8 \mathrm{CDF}$ & - & 0.3 & - \\
\hline
\end{tabular}

注1) $\mathrm{PCDD}, \mathrm{PCDF}$ は $\mathrm{ng} / \mathrm{Nm}^{3}$, その他は $\mathrm{mg} / \mathrm{Nm}^{3}$ • dry at $\mathrm{O}_{2} 11 \%$ とした.

2) ( ) 内の数字は $\mathrm{mg} / \mathrm{Nm}^{3} \cdot$ dry at $\mathrm{O}_{2} 12 \%$ とした. 
表 4 窒素酸化物低減対策の分類
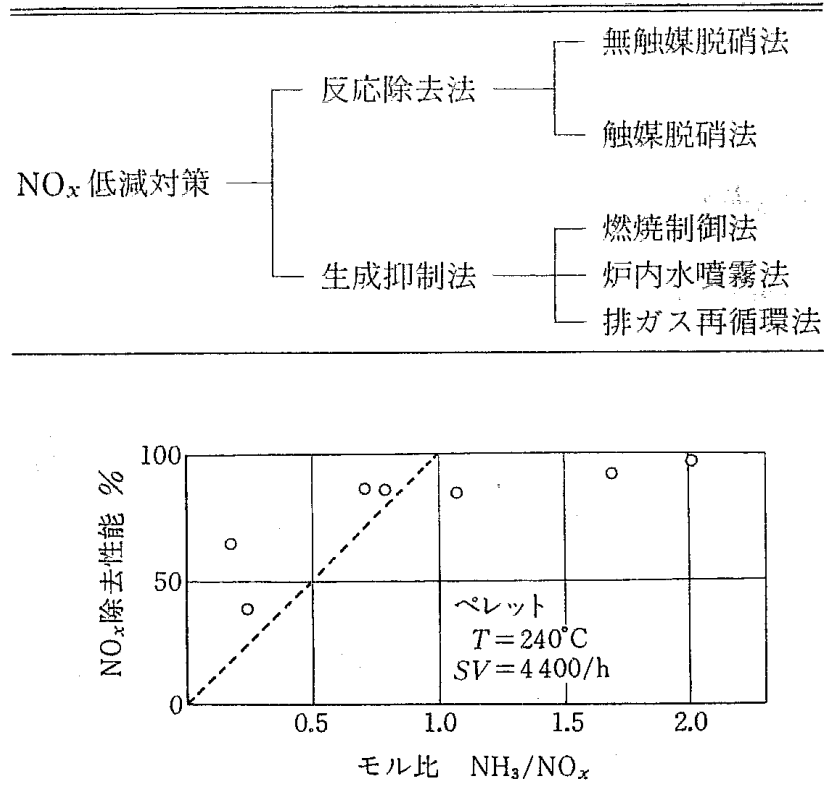

(a) 脱硝率とアンモニアモル比の関係 $\left(\mathrm{NH}_{3} / \mathrm{NO}_{x}\right)$ ( $T=240^{\circ} \mathrm{C}, S V=4400 / \mathrm{h}$ )

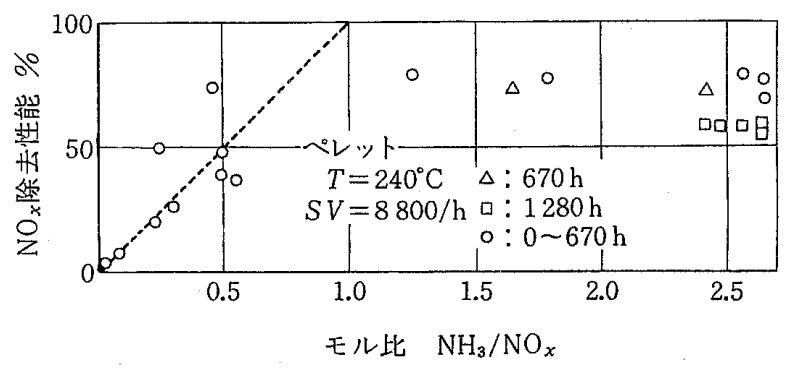

(b) 脱硝率とアンモニアモル比の関係 $\left(\mathrm{NH}_{3} / \mathrm{NO}_{x}\right)$ $\left(T=240^{\circ} \mathrm{C}, \quad S V=8800 / \mathrm{h}\right)$

図 $6 \mathrm{NO}_{x}$ 除去性能と $\mathrm{NH}_{3}$ 量 (ペレット)

リングしてもなかなか出くわす数值ではなかっ た、しかしながら最近，都市部においてはごみ質 が 1 ランク上がり，以前高質だったごみ質が基準 質と考えられ，さらに高質の場合， $3000 \mathrm{kcal} /$ $\mathrm{kg}$ に近づくこともある.

このようにごみ質が変化しているので当然のこ

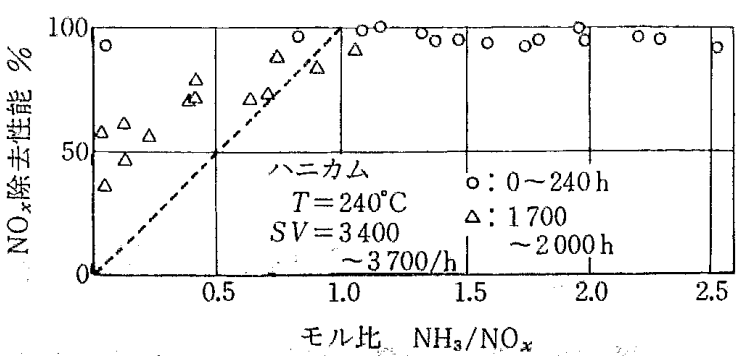

脱硝率とアンモニアモル比の関倸 $\left(\mathrm{NH}_{3} / \mathrm{NO}_{x}\right)$ $\left(T=240^{\circ} \mathrm{C}, S V=3400 \sim 3700 / \mathrm{h}\right)$

図 $7 \mathrm{NO}_{x}$ 除去性能と $\mathrm{NH}_{3}$ 量 (ハニカム)

とながら施設への影響も出よう、ヨーロッパ諸国 では微量有害物質の大気への排出が問題となりつ つあり，公害規制值がみな括され，以前にもまし てきびしい規制值がしかれているところもある。 我が国においても，都市開発化が全国的に進み， 廃菓物処理も都市開発形が望まれるようになりつ つある，従ってよりエネルギー回収形，効率的な 燃焼方法，公害規制值においても今以上きびしい 数値に対処出来る技術の蓄積が必要となる. 高温 燃焼技術， $\mathrm{NO}_{x}, \mathrm{HCl}$ ，微量有害物質などを複合 的に対処するコンパクトなガス処理技術に加え て，灰の安定化処理技術等の開発が今後期待され ることと思う。

\section{文献}

（1）日本機械学会「プラスチックごみの混合焼却処理に伴う 排ガス対策技術等に関する研究」，昭和 61 年度成果報告 書, (1987-3)，159〜216：218 250.

（2）鍋島，都市清掃，41-162（1988），35.

（3）石原・森本，都市清掃，41-162（1988），57.

（4）松野，都市清掃，41-162 (1988)，45.

（5）日名田・守屋，エネルギーコミュニケーション，No. 96 (1988)，8.

(6) ACHEMA 視察団, 化学工学, 52-9 (1988)，57.

（7）環境施設, 52-30 (1987).

（原稿受付 1988 年 11 月 29 日） 